\title{
POLITICAL THEOLOGY: \\ RELIGION AS LEGITIMIZING FICTION IN ANTIQUE AND EARLY MODERN CRITIQUE
}

\author{
Jan Assmann
}

In Greek texts of the fifth and fourth centuries we encounter the idea that religion, the belief in gods and their worship, is a human invention in the service of political power and social control. The earliest and most radical text, known under the designation of "the fragment of Critias" is an excerpt from a satirical play believed to be by Critias but now more convincingly attributed to Euripides. ${ }^{1}$ It is a speech put into the blasphemous mouth of Sisyphos, saying that the fear of the gods is nothing but the invention of a shrewd, intelligent and thoughtful man, meant to intimidate the wicked and keep them from committing evil in thought, word or deed. The problem is 'the evil' which is undiscovered and undiscoverable, committed in concealment and seclusion beyond the reach of public control. Starting from this calculation, he introduced the belief in gods. The idea of omniscient deities should persuade humans to keep the laws, even where no witnesses were present.

This can be read, both, as a critique of and an apology for religion. Religion is a fiction, but a legitimate fiction, because without religion there would be no law and social order; the weak would not be sheltered from the greed of the strong and crime would multiply without proportion. Any form of civil society requires the belief in $\operatorname{god}(\mathrm{s})$. A similar argument is used by Polybios in a fully positive sense. This author ascribes the success of Rome to the absolutely dominant position which the Romans gave religion within the structure of their state. "The greatest advantage of the Roman republic", he writes, "seems to me to lie in the belief in gods (peri theon dialepsei)." The Romans, he continues, granted this position to religion "for the sake of the masses" (dia plethous charin), a statement which seems to anticipate Marx's famous diction "Opium of the people."

Dihle (1977).

2 The following quotations are taken from Siculus (1969: 56.6-12). 
For this reason, Polybios continues, "the ancients seem to me to have deliberately inspired the masses with the ideas about the gods (peri theon ennoias) and the belief in the netherworld." Moreover, they had created tragedy as a medium to arouse visions of horror and anxiety in the masses in order to discipline them: "The masses are careless and full of illegal desires. The only means to restrain them is by vague fears (adelois phobois) and by such a spectacle (tragodia)." Polybios recognizes religion as a fiction, it is true, but as a great civilizing achievement and the foundation of social order, peace and harmony: thus, a "legitimate fiction." According to Polybios, it would be extremely unreasonable to cure the masses of these imaginations.

Still, Polybios, unlike Critias or Euripides, distinguishes between 'religion' and 'popular beliefs.' He does not say that the gods are fictitious, but that mass religion rests on fictitious concepts and imaginations. Mass religion is fictitious because it fulfils a political function. The political function of religion both legitimizes and criticizes. It legitimizes religion because it argues that the belief in gods is indispensable for political order and social harmony, and it criticizes it by exposing its fictitious character. Cicero, in De Natura Deorum, stresses the critical character of this argument, postulating that by representing the belief in gods in its totality as an invention of smart politicians, religion altogether is destroyed ${ }^{3}$ In Roman history, Numa Pompilius was held to be a model of such a smart politician. He appears in Roman tradition almost as a clone of Moses. Numa was said to have referred to the nymph Egeria as the source of his legislation just as Moses referred to Jahveh. Like Moses, Numa codified these laws in a book. Unlike Moses, however, he took this book along in his tomb instead of leaving it to posterity, thereby protecting it from later manipulation. In Roman tradition, Numa appears as a wise ruler and not as a religious impostor. He acquired this negative attribute only in the seventeenth and eighteenth century. The notorious pamphlet De Tribus Impostoribus exposing Moses, Jesus, and Mohammed as the prototypes of religious invention for political purposes quotes Numa as the most important pagan parallel, dedicating a whole chapter to him. ${ }^{4}$

3 "Quid i, qui dixerunt totam de dis immortalibus opinionam fictam esse ab hominibus sapientibus rei publicae causa, ut, quos ratio non posset, eos religio ad officium duceret, nonne omnem religionem funditus sustulerunt?" (Cicero 1995: 106).

${ }^{4}$ Schröder (1992: 72). 
An equally ambivalent statement is provided by Diodorus Siculus in a passage concerning the six great legislators of humanity. Diodorus intends for his account to be a demonstration of wise statesmanship without any critical, let alone denunciating, tendencies. In the seventeenth and eighteenth centuries, however, this passage became the most influential argument for exposing religion's fictitious character and political function. Moreover, it is the only quotation within the pagan critique of religion that explicitly mentions Moses. The first of these legislators, whom Diodorus calls Mnevis or Menas or Menes, is said to have stated that Hermes gave him these laws. In the same manner, Minos among the Cretes referred to Zeus, Lycurgus among the Spartans to Apollon, Zoroaster among the 'Arians' (arianoi = Persians) to Agathos Daimon (= Ahura Mazda), Zalmoxis among the Getans to Hestia and Moses among the Jews to Iao (= Yahveh). ${ }^{5}$ Again, Diodorus or his informant, perhaps Hecataeus of Abdera, does not aim at a critique of religion, but he rather describes this strategy, the framing of legislation by political theology, as a highly successful and fully legitimate device for the foundation of states and larger communities. In the fifteenth century, this passage provided the model for Marsilio Ficino's concept of 'theologia prisca.' Ficino interpreted the notions of legislation and the founding of states in the sense of theology and the founding of religions and replaced the great legislators with his concept of the ancient "sages:" Hermes Trismegist, Zoroaster, Moses, Orpheus, Pythagoras etc., who conveyed to humanity both religion and the rules of social order and civilized life.

Even in the first half of the seventeenth century, Gabriel Naudé (1600-1652) in his famous Considérations politiques sur les coups d'État could still quote and even enlarge Diodorus' argument in a totally neutral, uncritical sense:

Tous les anciens Législateurs voulant autoriser, affermir \& bien fonder les Loix qu'ils donnoient à leurs peuples, n'ont point eû de meilleur moïen de le faire, qu'en publiant \& faisant croire [... qu qu'ils les avoient reçûës de quelque Divinité: Zoroastre, d'Oromasis, Trismegiste de Mercure, Zalmoxis de Vesta, Charondas de Saturne, Minos de Jupiter, Lycurgue d'Apollon, Drago \& Solon de Minerve, Numa de la nymphe Egerie, Mahomet de l'Ange Gabriel; \& Moise, qui a été le plus sage

${ }^{5}$ Siculus (1956-1957: 94.1-2). 
de tous, nous décrit en l'Exode comme il reçût la sienne immédiatement de DIEU. ${ }^{6}$

It was only in the latter part of the seventeenth century that some 'free thinkers' discovered the critical potential in this tradition. Political theology came to be seen not only as the instrumentalization, but also as the invention of religion for political purposes. Arguing that religion served a function in the civilization of mankind and the build-up of political communities inevitably implied the critique that it is nothing but a function of politics, a fraudulent invention. The seventeenth chapter of the French Traité des Trois Imposteurs starts with this quote from Naudé and turns it into a devastating critique of religion, or, to be more precise, of 'revealed religion' - that is, of monotheism. ${ }^{7}$ The French pamphlet bears the name of Spinoza in its subtitle: Traité des Trois Imposteurs ou l'lesprit de Monsieur de Spinosa. It is obvious that the publication of Spinoza's Tractatus TheologicoPoliticus (1670) marks the turning point in the reception of Diodorus and the tradition about the six legislators. It is thus not inadequate to subsume the whole debate on the political instrumentalization or invention of religion under the term 'Political theology.' From Spinoza to Bakunin, political theology is a polemical term, denouncing theology or religion as the handmaid of politics.

Among the most interesting contributions to the debate about political theology are John Toland's Adeisidaemon, dealing with Numa Pompilius and with Cicero's summary of the Greek critique of religion, ${ }^{8}$ and Origines fudaicae, published together in 1709, dealing with Moses and taking Diodorus' passage on the six lawgivers as its starting point. In this booklet, Toland opposes the Biblical Moses, who followed the general principle in "inventing" (finxisse) a deity as the author of his legislation, with Moses of Strabon (Moses Strabonicus), who, conversely, rejected the principle or strategy of political theology in radical fashion. ${ }^{9}$

According to Strabo, an Egyptian priest named Moses, who felt dissatisfied with Egyptian religion, decided to found a new religion, and emigrated with his followers to Palestine. He rejected the Egyptian tradition of representing the gods in zoomorphic images. His reli-

\footnotetext{
Naudé (1988: 118 pp.).

Berti (1994: 198); Schröder (1992).

${ }^{8}$ Toland (1709).

${ }^{9}$ See Assmann (1998: 134 pp.).
} 
gion consisted of the recognition of only 'One Divine Being' whom no image could represent: "which encompasses us all, including earth and sea, that which we call the heavens, the world and the essence of things - this one thing only is God." The only way to approach this god is to live by natural law, in virtue and in justice. Later on, the Hebrews deviated from the purity of this doctrine and developed superstitious habits, such as dietary prohibitions, circumcision and various other laws.

Toland constructs the opposition between Egyptian traditional religion, with which Moses is said to have been dissatisfied, and the new religion instituted by Moses, in terms of political versus natural religion. He supplies the reasons for Moses' dissatisfaction by drawing on another passage in Diodorus, saying that each nome or province had its own deity ever since a certain, very sagely, prince ("sapientissimus quidam princeps") came to stabilize the concord of the kingdom by introducing a pluralistic and polytheistic religion ("variam \& miscellam induxit religionem"), and thereby to prevent a conspiracy among the Egyptians. Polytheism, according to Diodorus and Toland, has a political purpose. It stresses the political divisions and sub-identities by instituting tutelary deities, thus preventing unification and the formation of one political will, which this over-sage ruler seems to have feared as potentially rebellious. Strabon's Moses, in turn, was a deist and an iconoclast. He held God to be "Nature, or matter, mechanically arranged and acting without conscience and intelligence" ("Naturam, vel mundi materiam mechanice dispositam et absque ullam consia intelligentiam agentem") and was a fierce enemy of idolatry. Even the Bible shows that he did not make any mention of the immortality of the soul nor of a future state of reward or punishment. The name by which he called his god means just "necessariam solummodo existentiam," necessary existence or "what exists by himself" ("quod per se existit"), in the same sense that the Greek "to on" denotes the incorruptible, eternal, and interminable world. Toland obviously thinks of Ex. 3:14 where God presented himself to Moses: "I am that I am," or, in the version of the LXX: "ego eimi ho on" = "I am the Being one" or simply "I am Being." Moses was not an atheist, but a pantheist, or, to speak in conformity with more recent usage, a Spinozist.

Toland explains what Strabon describes as a later depravation of Moses' religion, with its innumerable commandments and prohibitions, by quoting a passage from Ezekiel: "But I shall give them 
statutes that are not good and laws by which they cannot live," ("Ego etiam dederam ipsis statuta non bona et Jura per quae non vivere possent"). ${ }^{10}$ In this way, religion turned into 'superstition.' The same distinction between religion and superstition occurs also in Toland's other pamphlet, Adeisidaemon. Here, 'religion of reason' is viewed as the only valid religion. Superstition is denounced a pseudoreligion, unable to withstand the criteria of reason, and invented by humans only for the purpose of supporting the political order in the sense of political theology. Political theology is a phenomenon of degeneration and the hallmark of 'false religion.'

Even more orthodox authors such as Alexander Ross availed themselves of this same argument. For them, political theology is the hallmark of pagan religion. In his book Pansebeia Ross writes: "All false Religions are grounded upon Policy," that is, "humane Policy to keep people in obedience and awe of their superiours". ${ }^{11}$ Similarly, the most important and influential treatment of questions concerning revelation and political theology, Bishop Warburton's The Divine Legation of Moses, has to be seen within this tradition. ${ }^{12}$ Warburton, however, is more of a classical scholar than a theologian. He agrees with Ross that polytheism or paganism is political theology and a human fiction, but he follows the antique tradition in taking these inventions as indispensable and therefore legitimate fictions without which all political and social order would collapse. Warburton gives two explanations for the political function of polytheism, one based on Critias and the other on Strabo. Polytheism, as political theology, fulfils two functions: first, the function of founding public morals and obedience to the laws, and, secondly, the function of mirroring and expressing on the divine plane the various distinctions and identities that make up the political and social world - the distinctions between nations, provinces and cities, and between classes, tribes and professional groups. Both functions cooperate to keep the subjects under control. Therefore, every society aiming at social order and political power must of necessity form a pantheon of tutelary deities,

${ }^{10}$ Ez. 20, 25. Toland deploys several other passages from the prophets rejecting cult on behalf of "nature" (on behalf of justice, to be precise, but this distinction seems to be immaterial in Toland's context).

11 The quotations are taken from the second edition, which was published in 1653 (Schröder 1998: 228).

${ }^{12}$ Warburton (1778); Assmann (1998: 138-170). 
by elevating important legislators, heroes and kings to the ranks of gods, and ascribing to them supervisory functions of the laws and personifications of political and social identities. But Warburton also takes the pagan gods to be a necessary, indispensable, and legitimate fiction, without which civil society could not last. Both, polytheism and idolatry, originate from and correspond to a political necessity, and form the political theology of paganism. ${ }^{13}$

So far, we have encountered four different positions concerning the political function of religion. All four agree in declaring political theology or political religion as false or fictitious. They differ in what they conceive of as truth in opposition to political theology. The most radical position, which is also the earliest attested one, is the position of Sisyphos in Critias' or Euripides' play Sisyphos. He declares religion as such and in toto to be a political fiction, implying the truth to be atheism. Less radical is Polybios' position, who speaks only of popular religion as a political fiction, implying that there is also a true or elite religion which is inaccessible to the masses. The position presented by the treatise De Tribus Impostoribus and also by the Spinozist Traité des trois imposteurs implies the opposition between revealed religion as false, because of its political function, and natural religion as true. The fourth position, for which we quoted Alexander Ross in the seventeenth and William Warburton in the eighteenth centuries, declares pagan religions to be false because they only serve political functions, and biblical religion to be true because it is based not on fiction but on revelation.

Warburton, however, being a classical scholar, combines the position of Polybios with that of Alexander Ross. He reconstructs pagan religions as "double religions" displaying an exoteric and an esoteric side. The political function and the fictitious character concerns only the exoteric side of pagan religion. The esoteric side, the 'mysteries,' are free of any political instrumentalization. This is also the reason for their concealment. The mysteries do not legitimize or support the state at all, because they are about nature or natural theology and nature, accordingly, would not know of moral obligations and

${ }^{13}$ It is important to realize that neither the atheist nor the deist critics of political theology and even those orthodox theologians who interpret political theology as the hallmark of paganism never put into doubt the necessity of theological fictions. Even the atheists, except extremists such as Knutzen and Meslier, do not plead for anarchy. See Schröder (1998: 228 pp.). 
political or social identities. But Warburton's theory is even more complex because, besides being a classical scholar, friend of Alexander Pope and editor of Shakespeare's works, he was also a bishop for the Anglican church; as such, he was constrained to reserve the highest place for revealed religion. This forced him to distinguish not only between false, i.e. political, and true, i.e. natural religion, but also between pagan and Christian religion. Pagan religion is not false but "double," comprising an exoteric political and an esoteric natural religion, as opposed to biblical religion which, because it is based on revelation, is simple.

Warburton's monumental work, nine books in three volumes, met with a very widespread and vivid reception; though not for its orthodox superstructure, but rather because of its theory of double or 'mysterious' religion. It was read as demonstrating that every religion, including biblical monotheism, had the structure of a double religion: a state-supportive, legitimizing façade and an esoteric inside, the mysteries of nature. It thus became a basic text for freemasonry. In 1786 and 1787, Carl Leonhard Reinhold, a Jesuit, student of philosophy, freemason and illuminate, wrote a book on the "Hebrew Mysteries or the Oldest Religious Freemasonry" 14 that was based on Warburton. This became a basic text not only for Masonic, but much wider circles of Deism, Enlightenment and philosophy, especially by mediation of Schiller, who condensed Reinhold's arguments and demonstrations into a widely read essay Die Sendung Moses. ${ }^{15}$

Reinhold equates the concept of 'nature' as the supreme deity of natural religion with Isis, the goddess of the Egyptian mysteries, who, in the inscription on her "veiled image at Sais" presents herself with the words "I am all that is, was and will be. No mortal unlifted my veil." This, according to Reinhold, is the deity in whose mysteries Moses was initiated when he was educated as a prince at the Pharaonic court. When Moses later returned to his native people, he wanted to acquaint his people with the deity of the mysteries, whose presentation he translated for them not as "I am all that is," but as "I am Being." This is how Reinhold interprets Ex 3:14, "eh"yeh asher eheyeh" "I am that I am"). However, because Moses wanted to include the whole people into the mysteries of nature, and because

${ }^{4}$ A quote from Karl Leonhard Reinhold [1788]. See Assmann (2001).

${ }^{15}$ Schiller (1968: 737-757); Assmann (1998: 186-205); Hartwich (1997: 21-47). 
he could not possibly "initiate" them (an educational process taking many years and requiring only the strongest and most intelligent minds), he had to turn the mysteries of Isis into a public and political religion, based on blind belief and obedience, and to turn Isis, the sublime deity of the mysteries, into Yahveh, a national god. Thus biblical monotheism, because of its political function in supporting the Jewish nation and commonwealth, has to be classified among the false religions - its only element of truth, which Moses was able to rescue from the Egyptian mysteries, being the unity or oneness of God.

Yet according to Schiller, Moses was not an impostor, but just an "accommodator." According to Schiller "His enlightened mind and his sincere and noble heart" had revolted against the idea of giving his people a false and fabulous god. But the truth, the religion of reason and nature, was equally impossible to reveal. Eventually, the only solution was to proclaim the truth in a fabulous way and to endow the true god with some fictitious properties and qualities that the people would be able to grasp and to believe in. ${ }^{16}$ Thus, Moses couched his vision of truth in the illusionistic form of a national god and a national cult, including the whole 'hieroglyphic' symbolism of lustrations, sacrifices, processions, oracles, and so forth. With Schiller we approach the point where religion is defined as "Opium of the people" (Marx) and as an "illusion" (Freud).

Through this transformation process, the topic of political theology finally reached Mikhail Aleksandrovitch Bakunin (1814-1876), the exponent of romanticist anarchy, who no longer concedes religion's legitimacy and indispensability as political fiction. His motto is the inversion of Voltaire's verse "Si dieu n'existait pas il faudrait l'inventer," which proclaimed: "Si dieu existait il faudrait l'abolir" ("If God existed he should be abolished"). Up to Bakunin, almost all critics of religion, including Sisyphos in Euripides' play, agreed that, without the fiction of god or gods, all moral, legal and political order would vanish. Bakunin, on the other hand, holds that religion

16 "Should he proclaim to them a false and fabulous god, against whom his reason revolts, whom he learned in the mysteries to detest? For this, his mind is too enlightened, his heart too noble and sincere... How may these contradictions may reconciled? He cannot proclaim the true god to the Hebrews, because their mind is unable to grasp him; he does not want to give them a false god because he despises this adverse role. Nothing is left to him but to proclaim to them his true god in a fabulous way" (Assmann 2001: 756 pp., my translation). 
must be abolished because of its political theology. Political theology has now become an unequivocally polemical term, denouncing religion as a tool of oppression in the hands of the ruling classes. Religion can and must be disposed of, because humankind has the reason and the power of their own to establish institutions of decent society.

It is in Bakunin's writings that Carl Schmitt detected the term 'political theology' and redefined it in a positive sense. Schmitt does not share Bakunin's positive anthropology. Instead, he falls back to the pessimistic anthropology of Christianity in general with its doctrine of original sin, and to the seventeenth century in particular and Hobbes' ideas of the natural state as bellum omnium contra omnes. In the light of such a pessimistic view of man, not religion, but political order, the state, becomes indispensable. Again, the notion of indispensability acquires a religious aura. Political power is good, because it is indispensable, and this goodness or sacredness of power is expressed by St. Paul in the words that it is "of God." Not "false religion is political," but "true politics is theological;" summarizes Schmitt's version of the debate on the relation between religion and politics. True politics is theological because it knows that its power comes from God. All the salient political concepts - this is Schmitt's thesis are secularized theological concepts. With Schmitt, political theology is still a polemic, but with the direction of the polemic radically changed - even inverted. It no longer implies a critique of religion, but a critique of politics. False politics is denounced by political theology as neglectful of its divine fundaments and origins. False politics bases itself on a positive anthropology, imagining that it could do without God. False politics still according to Carl Schmitt is the politics of secularism, individualism, democracy, and free-market economy, the politics of sovereign, autonomous, this-worldly man, believing himself able to negotiate the principles of truth, order and justice on a totally secular and rational basis.

In a particular fashion, Schmitt is right to use the term "political theology" as a critique of politics; this corresponds to the original meaning of biblical monotheism. In the Books Exodus through Deuteronomy, monotheism is represented as a liberation movement, directed against pharaonic totalitarianism. In the confrontation between Egypt and Israel, Egypt stands for oppression, humiliation, and dehumanization, while Israel stands for the principles of decent society. The original meaning of biblical monotheism is deeply political and its theology is, above all, political theology, i.e. covenant theology. 
This is, however, not what Carl Schmitt had in mind. The sovereign state which Schmitt advocated corresponds more to ancient Egypt than to ancient Israel.

\section{REFERENCES}

Assmann, Jan (1998). Moses der Ägypter. Entzifferung einer Gedächtnisspur. Munich: Hanser. —. (ed.) (2001). Carl Leonhard Reinhold. Die Hebräischen Mysterien oder die älteste religiöse Freymaurerey. Neckargemünd: Mnemosyne.

Berti, Silvia (1994). Trattato dei tre impostori. La vita e lo spirito del Signor Benedetto di Spinoza. Turin: Einaudi.

Cicero, Marcus Tullius (1995). De natura deorum. Über das Wesen der Götter. Stuttgart: Reclam.

Dihle, Albrecht (1977). "Das Satyrspiel ,Sisyphos'." In: Hermes 105: 28-42.

Hartwich, Wolf-Daniel (1997). Die Sendung Moses. Von der Aufklärung bis Thomas Mann. Munich: Fink.

Naudé, Gabriel (1988). Considérations politiques sur les coups d'État. Paris: Les Éditions de Paris.

Schiller, Friedrich (1968). "Die Sendung Moses." In: Koopmann, Helmut (ed.). Sämtliche Werke IV: Historische Schriften. Munich: Winkler-Verlag. 737-757.

Schröder, Winfried (1992). Traité des Trois imposteurs. Hamburg: Meiner.

- (1998). Ursprünge des Atheismus. Untersuchungen zur Metaphysik - und Religionskritik des 17. und 18. Jahrhunderts. Stuttgart-Bad Cannstadt: Frommann-Holzboog.

Siculus, Diodorus (1956-57). Bibliotheca Historica I. London: Oxford University Press.

- (1969). Bibliotheca Historica VI. Lipsiae: Teubner.

Toland, John (1709). Adeisidaemon, sive Titus Livius a superstitione vindicatus. Annexae sunt ejusdem Origines judaicae [sive, Strabonis, de Moyse et religione judaica historia, breviter illustrata]. The Hague: Thomam Johnson.

Warburton, William [1738-1741] (1778). The divine legation of Moses demonstrated on the principles of a religious deist, from the omission of the doctrine of a future state of reward and punishment in the Jewish dispensation. 4 vols. London. 